\title{
Influence of oestrogens on muscarinic receptor density and contractile response in the guinea-pig uterus
}

\author{
R. Matucci ${ }^{1}$, B. Bianchi ${ }^{2}$, L. Mantelli ${ }^{1}$, C. Ghelardini ${ }^{1}$, G. B. Vannelli ${ }^{3}$ \\ and M. Maggi ${ }^{4}$ \\ ${ }^{1}$ Department of Preclinical and Clinical Pharmacology, ${ }^{2}$ Institute of Clinical Dermatology, ${ }^{3}$ Department of \\ Human Anatomy and Histology and ${ }^{4}$ Department of Clinical Physiopathology, Endocrinology Unit, \\ University of Florence, I-50134 Florence, Italy
}

\begin{abstract}
The objective of this study was to investigate the contractile response in vitro of uterine and myometrial strips from control and oestrogen-treated guinea-pigs to carbachol. In addition, the muscarinic receptor parameters in subcellular preparations from the myometrium of the same animals were evaluated. Strips of guinea-pig uterus contract in response to carbachol in a concentration dependent manner and the effect of carbachol is independent of the presence of an intact endometrium. However, treatment with oestrogen reduces the response to carbachol, when expressed with respect to the effect of $\mathrm{KCl}$. Measurement of the specific binding of $\left[{ }^{3} \mathrm{H}\right]$ quinuclidinyl benzylate $\left(\left[{ }^{3} \mathrm{H}\right] \mathrm{QNB}\right)$ to myometrial membranes from control and oestradiol-treated immature guinea-pigs showed that oestradiol significantly decreased the number of specific binding sites of $\left[{ }^{3} \mathrm{H}\right] \mathrm{QNB}$, but did not change the apparent affinity of specific $\left[{ }^{3} \mathrm{H}\right] \mathrm{QNB}$ binding. Moreover, the apparent affinity constants for the different antagonists showed a close similarity to those obtained at muscarinic receptors present in the myometrium from control and oestradiol-treated guinea-pigs.
\end{abstract}

\section{Introduction}

Uterine activity is regulated by complex and mutual interactions among sex steroids, neurohypophyseal hormones and neurotransmitters (Maggi et al., 1994a, b). Oestrogens increase the myometrial responsiveness to neurohypophyseal hormones (Maggi et al., 1988), endothelin-1 (Maggi et al., 1991), serotonin (Ichida et al, 1983) and $\alpha$-adrenergic agonists, without affecting the $\beta$-adrenergic response (Roberts et al., 1977). Hence, it is generally accepted that oestrogens sensitize the myometrium to the effect of uterotonic substances. The effect of oestrogen, which alters sensitivity to hormones and neurotransmitters, is apparently mediated by a specific upregulation of the related receptors.

Cholinergic drugs stimulate uterine contraction in several mammals, including rats (Ichida et al., 1983, 1984; Leiber et al., 1984; Varol et al., 1989), rabbits (Riemer et al., 1987a) and guinea-pigs (Garris et al., 1984; Marc et al., 1986). Their effect is mediated by specific interactions with muscarinic receptors present on smooth muscle fibres (Crankshaw, 1984). In guineapig myometrium, muscarinic receptors are coupled to an increase in inositol phosphate turnover (Marc ef al., 1986) and apparently belong to the $\mathrm{M}_{2}$ receptor subtype (Eglen et al., 1989; Doods et al., 1993). Conversely, in rat myometrium the $\mathrm{M}_{3}$ receptor subtype is predominant (Varol et al., 1989).

Although the uterus is relatively sensitive to cholinergic stimulation, little is known about the effect of oestrogen on muscarinic receptors. Treatment with oestrogen increases

Received 22 September 1995.
(Parkington and Lipton, 1976), decreases (Garris et al., 1984) or does not affect (Riemer et al., 1987b) cholinergic responsiveness in the uterus. This apparent discrepancy could be the result of species-related differences or to differential expression of muscarinic receptor subtypes. Because myometrial muscarinic receptors in guinea-pigs have been extensively characterized using radioligand and cDNA probes (Eglen et al., 1989; Doods et al., 1993), we investigated the effect of administration of oestrogen in guinea-pigs. We evaluated whether subacute oestrogen treatment affects muscarinic receptor density, ligand specificity or myometrial responsiveness. Our results suggest that oestrogen inhibits the expression of muscarinic receptors without changing the subtype of muscarinic receptor expressed.

\section{Materials and Methods}

\section{Materials}

17ß-Oestradiol-3-benzoate, benzamidine hydrochloride, trypsin inhibitor (type I-S from soybean), DL-dithiothreitol, bacitracin zinc salt and S-( - )-hyoscyamine were obtained from Sigma Chemical Company, St Louis, MO. $\left[{ }^{3} \mathrm{H}\right] \mathrm{Quinudlidinyl}$ benzylate $\left(\left[{ }^{3} \mathrm{H}\right] \mathrm{QNB}\right.$, specific activity $\left.32.9 \mathrm{Ci} \mathrm{mmol}{ }^{-1}\right)$ was from New England Nuclear, Boston, MA. Hexahydrosila-difenidol hydrochloride $p$-fluoro analogue ( $p$-F-HHSiD), ( \pm )-quinuclidinyl- $\alpha$-hydroxydiphenyl acetate (QNB) and 4-diphenylacetoxy- $N$-methylpiperidine methiodide (4-DAMP) were from Research Biochemicals Inc., Natick, MA. Pirenzepine 
hydrochloride and II-[2-[(diethylamino)methyl]-1-piperidinyl]acetyl $] 5,11$-dihydro- $6 H$-pyrido[2,3-b][1,4]benzodiazepine-6one (AF-DX116) were obtained from Thomae, Biberach. Methoctramine tetrahydrochloride was a generous gift from $\mathrm{C}$. Melchiorre, Bologna. Telenzepine hydrochloride was kindly donated by Byk Gulden Italia (Milan). $R-(+)$-hyoscyamine was prepared in the Department of Pharmaceutical Sciences of the University of Florence, according to the method described by Gualtieri et al. (1991). All other chemicals were of analytical grade and were purchased from commercial sources.

\section{Animals}

Virgin immature female Dunkin-Hartley guinea-pigs (approximately $200 \mathrm{~g}$ body mass, $4-5$ weeks old) were obtained from Rodentia (Torre Pallavicina, Bergamo). They were housed six to a cage with free access to food and water and maintained in a $12 \mathrm{~h}$ light:12 $\mathrm{h}$ dark cycle at an ambient temperature of $22^{\circ} \mathrm{C}$.

$17 \beta$-Oestradiol-3-benzoate $(40 \mu \mathrm{g}$ per $200 \mathrm{~g}$ ) or vehicle were administered once a day for 4 consecutive days and animals were killed on the following day. Steroid hormones were dissolved in absolute ethanol, brought to a final concentration of $1.5 \%(\mathrm{v} / \mathrm{v})$ ethanol in peanut oil, and injected s.c.

This investigation conformed to the rules for the care and use of laboratory animals of the European Community (86/609/CEE).

\section{Recording of mechanical activity}

Strips of guinea-pig uterus ( $2 \mathrm{~mm}$ wide, $15 \mathrm{~mm}$ long) were obtained from immature control or oestradiol-treated guineapigs. The endometrium was carefully removed by rubbing with gauze; strips were suspended in an organ bath under $1 \mathrm{~g}$ resting tension, and superfused with Sund's physiological solution of the following composition ( $\mathrm{mmol} \mathrm{l}^{-1}$ ): $\mathrm{NaCl} 154$, $\mathrm{KCl}$ 5.63, $\mathrm{CaCl}_{2}$ 0.54, $\mathrm{MgCl}_{2}$ 0.95, $\mathrm{NaHCO}_{3}$ 5.95, glucose 2.78. The solution was oxygenated with $95 \% \mathrm{O}_{2}$ and $5 \% \mathrm{CO}_{2}$ and maintained at $30^{\circ} \mathrm{C}$. Isometric contractions were recorded by means of an isometric transducer on a chart polygraph (Battaglia Rangoni KV 135). After an equilibration period of at least $60 \mathrm{~min}$, during which the solution was replaced every $15 \mathrm{~min}$, cumulative concentration-response curves to carbachol were obtained. Since the guinea-pig uterus showed a loss of sensitivity in successive curves of carbachol, only one concentration-response curve was determined in a single preparation. The response to $60 \mathrm{mmol} \mathrm{KCl} l^{-1}$, a nonspecific activator of contraction, was determined for each strip, 15-30 min after washing out the carbachol. The response to carbachol was evaluated as net increase in force, measured as $\mathrm{mg}$ and as percentage response in comparison with the contractile effect of $\mathrm{KCl}$ (E-carbachol: $\mathrm{E}-\mathrm{KCl})$.

\section{Membrane preparation}

Uteri were removed, washed in saline solution and freed from fat and loosely bound connective tissue. For binding studies, the myometrium was prepared free of endometrium by scraping with the handle of the scalpel (Riemer $e t$ al., 1986).
Membranes were prepared as described by Maggi et al. (1988). Myometrium was weighed and minced with fine scissors in 5 volumes of buffer 1 ( $10 \mathrm{mmol}$ Tris- $-\mathrm{HCl} \mathrm{l}^{-1}$, $\mathrm{pH} 7.4$, containing $1.5 \mathrm{mmol}$ EDTA $\mathrm{I}^{-1}, 0.5 \mathrm{mmol}$ dithiothreitol $1^{-1}, 1 \mathrm{mmol}$ benzamidine $\mathrm{I}^{-1}, 0.01 \%(\mathrm{w} / \mathrm{v})$ bacitracin, $0.002 \%(\mathrm{w} / \mathrm{v})$ soybean trypsin inhibitor). Thereafter it was homogenized with an Ultra-Turrax apparatus, filtered through two layers of cheese cloth and then homogenized again using a glass-teflon homogenizer. The homogenate was centrifuged at $1000 \mathrm{~g}$ for $10 \mathrm{~min}$ and the pellets were discarded; the supernatants were then centrifuged at $105000 \mathrm{~g}$ for $45 \mathrm{~min}$. Pellets from this spin were dispersed in buffer $2\left(50 \mathrm{mmol}\right.$ Tris-maleate $1^{-1}, \mathrm{pH} \mathrm{7.6}$, containing $10 \mathrm{mmol} \mathrm{MgSO}_{4} \mathrm{I}^{-1}, 1 \mathrm{mmol}$ benzamidine $\mathrm{l}^{-1}, 0.01 \%(\mathrm{w} / \mathrm{v})$ bacitracin and $0.002 \%(\mathrm{w} / \mathrm{v})$ soybean trypsin inhibitor) with a glass-teflon homogenizer and centrifuged again at $105000 \mathrm{~g}$ for $45 \mathrm{~min}$.

The final pellet was resuspended in buffer 2 to give protein concentrations of $2-5 \mathrm{mg} \mathrm{ml}^{-1}$ and stored frozen at $-80^{\circ} \mathrm{C}$ in small fractions until used for ligand binding studies.

The protein concentration of each membrane fraction was determined using the Pierce protein assay reagent (Pierce Chemicals, Rockford, IL), based on the method of Bradford with BSA as standard (Bradford, 1976).

The DNA content was measured according to the method of Labarca and Paigen (1980).

\section{Cholinergic receptor binding assays}

All binding assays were performed in triplicate in buffer 2 using $\left[{ }^{3} \mathrm{H}\right] \mathrm{QNB}$ with a specific activity of $32.9 \mathrm{Ci} \mathrm{mmol}^{-1}$. Incubations were carried out in a final volume of $300 \mu \mathrm{l}$ at $25^{\circ} \mathrm{C}$ for $30 \mathrm{~min}$, unless otherwise indicated.

In homologous competition curves $\left[{ }^{3} \mathrm{H}\right] \mathrm{QNB}$ was present at $0.2 \mathrm{nmol} 1^{-1}$ in tubes containing increasing concentrations $\left(0.3-10000 \mathrm{nmol} \mathrm{l^{-1 }}\right)$ of unlabelled QNB, and at $0.01-0.2 \mathrm{nmol} \mathrm{I}^{-1}$ in tubes without unlabelled ligand. In the heterologous competition curves fixed $\left(0.2 \mathrm{nmol} \mathrm{l}^{-1}\right)$ concentrations of the tracer were displaced by increasing concentrations of several unlabelled ligands (1-100000 nmol $1^{-1}$ ). Muscarinic receptor subtypes were characterized by examining $\left[{ }^{3} \mathrm{H}\right] \mathrm{QNB}$ binding in the presence of several muscarinic antagonists such as the $M_{1}$ selective antagonists, pirenzepine and telenzepine, the $M_{2}$ selective antagonists, AF-DX116 and methoctramine, and 4-DAMP and p-F-HHSiD, which exhibit high affinity for the $M_{3}$ muscarinic receptor.

After incubation, the reaction was stopped using $5 \mathrm{ml}$ $50 \mathrm{mmol}$ Tris- $\mathrm{HCl} \mathrm{l}^{-1}$ cold buffer, $\mathrm{pH} 7.4$; the reaction mixture was then drawn under vacuum through GF/B filter papers using a Brandel $\mathrm{M}-48$ cell harvester. The glass-fibre filter papers were presoaked in $0.1 \%(\mathrm{w} / \mathrm{v})$ polyethylenimine to reduce nonspecific binding to the filters. Then the filters were washed twice with $5 \mathrm{ml}$ ice-cold buffer and partially dried under vacuum. The filter papers were placed in polyethylene vials with $4 \mathrm{ml}$ Filter-Count (Packard Instrument, Groningen) and the amount of radioactivity recorded in a TRI-CARB 1900TR (Packard). 


\section{Histology}

Uterine and myometrial specimens derived from control and oestradiol-treated guinea-pigs were fixed by immersion in Bouin's solution. After fixation, the tissues were embedded in paraffin wax and sections of about $5 \mu \mathrm{m}$ thickness were cut. Paraffin wax was removed from the sections, and they were stained with haematoxylin-eosin and observed and photographed using a Nikon MICROPHOT-FX microscope (Nikon, Kogaru, Tokyo).

\section{Statistical analyses}

Data were analysed by the weighted least-squares iterative curve fitting LIGAND program (Munson and Rodbard, 1980) to obtain the dissociation constants $\left(K_{\mathrm{i}}\right)$ of the six muscarinic antagonists. The ALLFIT program (De Lean et al, 1978) was used for the analysis of sigmoidal dose-response curves obtained in the binding studies. This program uses the constrained fourparameter logistic model to obtain the half-maximal ineffective concentration $\left(\mathrm{IC}_{50}\right)$ values and the logit-log slope (pseudo Hill coefficient, $\mathrm{nH}$ ).

$p D_{2}$ values of carbachol ( $-\log$ of the half-maximal effective concentrations) were evaluated according to the GRAPHPAD program, edited by Harvey Motulsky (University of San Diego, 1985).

All statistically significant differences were assessed using Student's $t$ test, and $P<0.05$ was considered significant. All values quoted are means \pm SEM.

\section{Results}

\section{Effect of the injection of oestradiol}

An increase in uterine wet mass was observed in tissue from oestradiol-treated animals compared with controls. In fact, $40 \mu \mathrm{g}$ oestradiol per $200 \mathrm{~g}$ of body mass daily for 4 days caused more than a $300 \%$ increase in the wet mass of the uteri compared with the control group (control: $218 \pm 17 \mathrm{mg}$, $n=22$; oestradiol-treated: $676 \pm 24 \mathrm{mg}, n=19, P<0.001$ ). In a limited number of guinea-pigs, there was a significant decrease in the DNA:protein ratio (control: $0.85 \pm 0.06, n=5$, oestradiol-treated: $0.46 \pm 0.09, n=5, P<0.001$ ).

\section{Histological studies}

Histological sections of myometrial preparations confirmed the presence of two distinct muscular layers (longitudinal and circular), free of endometrium, both in control and in oestradioltreated animals (Fig. 1c, d). Morphological details of intact uterine tissues are shown (Fig. 1a, b).

\section{Contractility studies}

In uterine strips derived from immature guinea-pigs, carbachol $\left(50 \mathrm{nmol} \quad 1^{-1}-10 \mu \mathrm{mol} \quad 1^{-1}\right)$ produced a concentration-dependent increase in contraction. The maximum effect was obtained with $10 \mu \mathrm{mol}$ carbachol $\mathrm{l}^{-1}$, and consisted of a net increase in tension of $2023 \pm 223 \mathrm{mg}$. In the same preparations, $60 \mathrm{mmol} \mathrm{KCl} \mathrm{l^{-1 }}$ produced a contraction of $863.0 \pm 105.1 \mathrm{mg}$. The concentration-response curve to carbachol, expressed as the ratio of different responses to carbachol to the response to $60 \mathrm{mmol} \mathrm{KCl} \mathrm{l^{-1 }}$ (E-carbachol:E- $\mathrm{KCl}$ ), is shown Fig. 2). The $\mathrm{pD}_{2}$ value for carbachol is $6.49 \pm 0.07$. Similar results were obtained in endometrium-free uterine strips (data not shown). In these preparations, the maximum response to carbachol was $1738 \pm 280 \mathrm{mg}$, and the E-carbachol:E-KCl ratio was $2.34 \pm 0.08$.

Strips obtained from oestrogen-treated guinea-pigs contracted at higher concentrations of carbachol, since the first concentration of carbachol that could induce a measurable response was $0.2 \mu \mathrm{mol} \mathrm{I}^{-1}$. The net increases in tension produced by $10 \mu \mathrm{mol}$ carbachol $\mathrm{l}^{-1}$ and by $60 \mathrm{mmol} \mathrm{KCl} \mathrm{I}^{-1}$ were $3357 \pm 166.3 \mathrm{mg}$ and $2308 \pm 88 \mathrm{mg}$, respectively. Hence, the concentration-response curve is expressed as $\mathrm{E}$-carbachol:E-KCl. The $p D_{2}$ value in these preparations was $6.37 \pm 0.11$ (Fig. 2). Again, removal of endometrium in oestrogen-treated animals did not modify either the response to carbachol or to $\mathrm{KCl}$. The effect of $10 \mu \mathrm{mol}$ carbachol $1^{-1}$ was a contraction of $3395 \pm 259.8 \mathrm{mg}$ and the effect of $\mathrm{KCl}$ was a contraction of $2430 \pm 243.8 \mathrm{mg}$.

\section{Radioligand binding studies}

The specific binding of $\left[{ }^{3} \mathrm{H}\right] \mathrm{QNB}$ to guinea-pig myometrial membranes was linear with protein concentrations ranging from $20-270 \mu \mathrm{g}$ per tube (data not shown), with a correlation coefficient of 0.999 . For binding experiments, a membrane protein concentration of about $60 \mu \mathrm{g}$ per tube was chosen.

Binding reactions of $\left[{ }^{3} \mathrm{H}\right] \mathrm{QNB}$ to myometrial membranes from control and oestradiol-treated guinea-pig uteri were time and temperature dependent. The time course of $\left[{ }^{3} \mathrm{H}\right] \mathrm{QNB}$ specific binding revealed a rapid rise in $\left[{ }^{3} \mathrm{H}\right] \mathrm{QNB}$ binding, which reached a plateau at $5-10 \mathrm{~min}$ at 25 and $37^{\circ} \mathrm{C}$, while $120 \mathrm{~min}$ was not enough to reach the plateau if the membranes were incubated at $0-4^{\circ} \mathrm{C}$. The results of time and temperature dependence of $\left.{ }^{3} \mathrm{H}\right] \mathrm{QNB}$ binding $\left(2 \mathrm{nmol} \mathrm{^{-1 }}\right)$ to membranes derived from control and oestradiol-treated guinea-pigs, respectively, are shown (Fig. 3).

Scatchard analysis of $\left[^{3} \mathrm{H}\right] \mathrm{QNB}$ saturation curves indicated a linear relationship in both cases, suggesting the presence of a single class of high affinity, high capacity binding sites. A representative Scatchard plot (Fig. 4) shows that oestradiol treatment greatly affected binding capacity, without changing affinity. Indeed in five separate experiments, the $B_{\max }$ was significantly blunted in oestradiol-treated uteri $\left(1390.2 \pm 63.9 \mathrm{fmol} \mathrm{mg}^{-1}\right.$ protein versus $701.9 \pm 33.2 \mathrm{fmol}$ $\mathrm{mg}^{-1}$ protein, $P<0.001$ ), while the $K_{\mathrm{d}}$ value was unchanged $\left(0.29 \pm 0.04 \mathrm{nmol} \mathrm{l}^{-1}\right.$ versus $\left.0.22 \pm 0.02 \mathrm{nmol} \mathrm{l}^{-1}\right)$.

The $\left[{ }^{3} \mathrm{H}\right] \mathrm{QNB}$ binding was inhibited by pirenzepine and telenzepine $\left(M_{1}\right.$ selective antagonists; Hammer et al., 1980; Hammer and Giachetti, 1982), AF-DX116 and methoctramine $\left(\mathrm{M}_{2}\right.$ selective antagonists; Melchiorre et al., 1987; Micheletti et al., 1987) and 4-DAMP and p-F-HHSiD ( $\mathrm{M}_{3}$ selective antagonists; Barlow et al., 1976; Lambrecht et al., 1989).

All different antagonists tested displaced $\left[{ }^{3} \mathrm{H}\right] \mathrm{QNB}$ with the same high affinity in membranes from both control and 

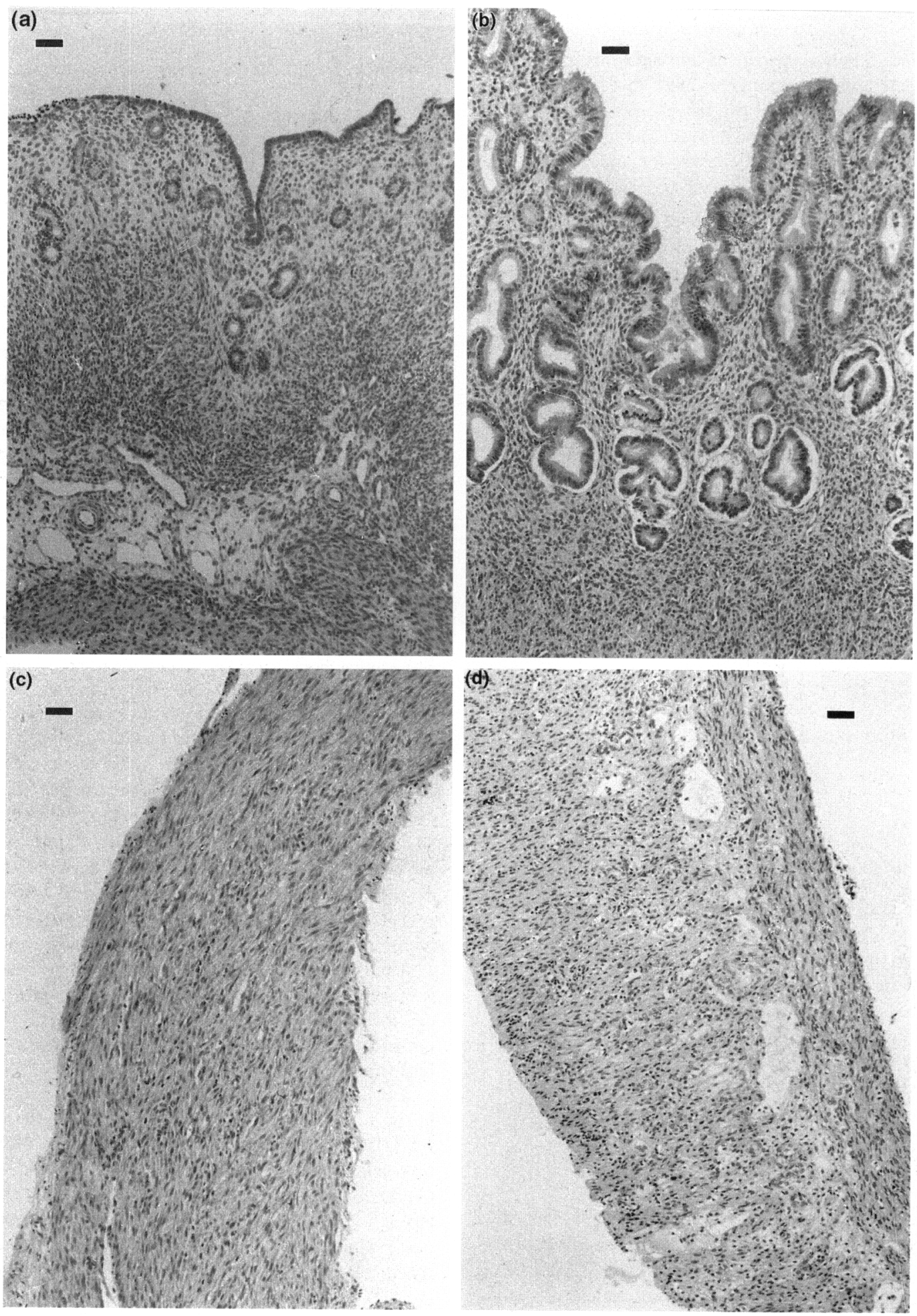

Fig. 1. Photomicrographs of uterine tissue from (a) immature and (b) oestradiol-treated guinea-pigs; myometrial uterine tissue after endometrium removed from (c) immature and (d) oestradiol-treated guinea-pigs are shown (haematoxylin-eosin stained). Scale bars represent $0.16 \mathrm{~mm}$.

oestradiol-treated animals. Computer analysis of competition curves was performed using the method previously described (ALLFT) and no statistical differences appear between the parameters of the sigmoidal dose-response curves obtained in binding using the same substance in the two myometrial preparations. 


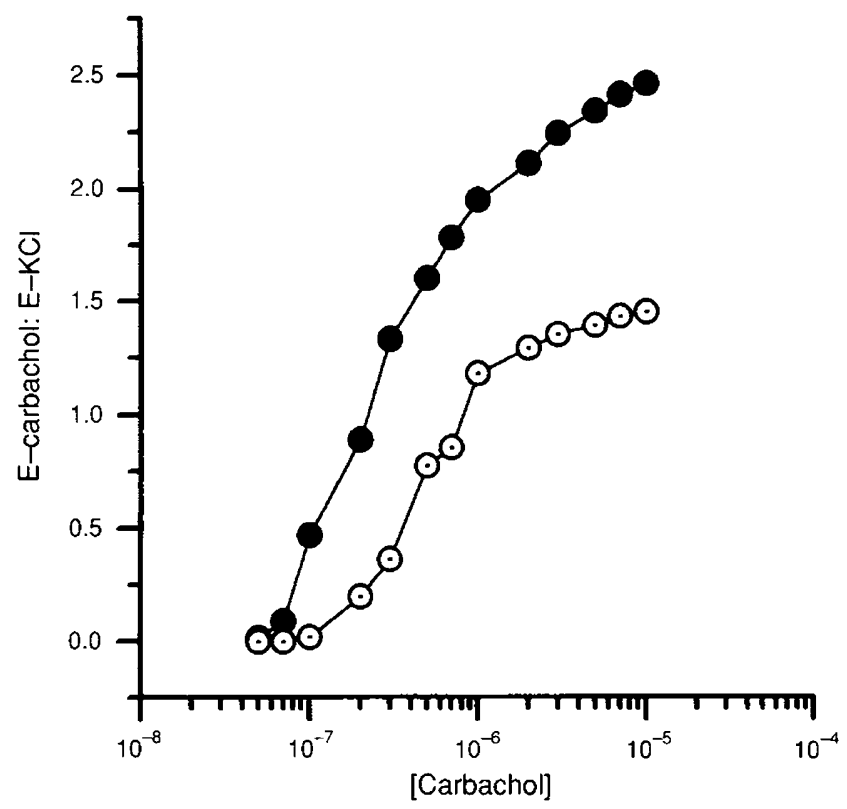

Fig. 2. Isometric contractile response to carbachol. Uterine strips from control ( ) and oestradiol-treated $(O)$ guinea-pigs were incubated in Sund's solution at $30^{\circ} \mathrm{C}$ in the presence of the indicated concentrations of carbachol. The data are means of the pooled responses from at least 15 uterine strips, expressed as the ratio of the response to carbachol: to the response to $60 \mathrm{mmol} \mathrm{KCl} \mathrm{l}^{-1}$. No error bars are shown, because the errors were within the size of the symbols.

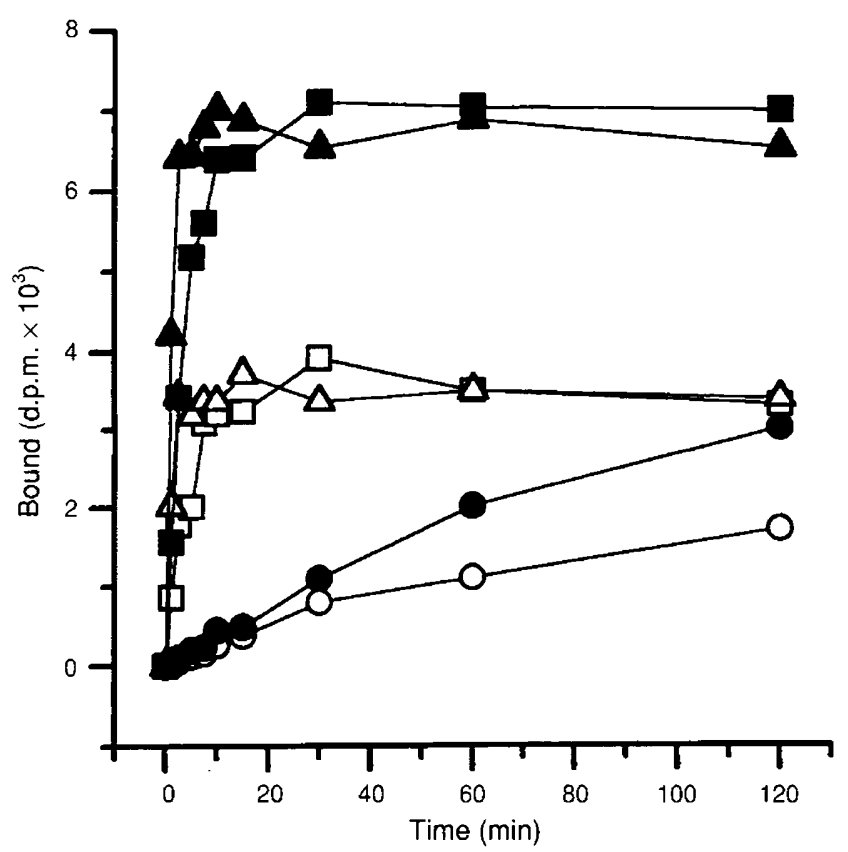

Fig. 3. Time and temperature dependence of specific $\left[{ }^{3} \mathrm{H}\right]$ quinuclidinyl benzylate $\left.\left({ }^{3} \mathrm{H}\right] \mathrm{QNB}\right)$ binding to membranes prepared from control (closed symbols) and oestradiol-treated (open symbols) guinea-pigs. Myometrial membranes ( $60 \mu \mathrm{g}$ per tube) were incubated with $2 \mathrm{nmol}$ $\left[{ }^{3} \mathrm{H}\right.$ ]QNB I ${ }^{-1}$ with or without $10000 \mathrm{nmol}^{-1}$ of the unlabelled $\mathrm{QNB}$ (to measure nonspecific binding) for different durations at $0-4^{\circ} \mathrm{C}$ (C. $\bigcirc), 25^{\circ} \mathrm{C}(\boldsymbol{\square}, \square)$ and $37^{\circ} \mathrm{C}(\boldsymbol{\Delta}, \triangle)$.

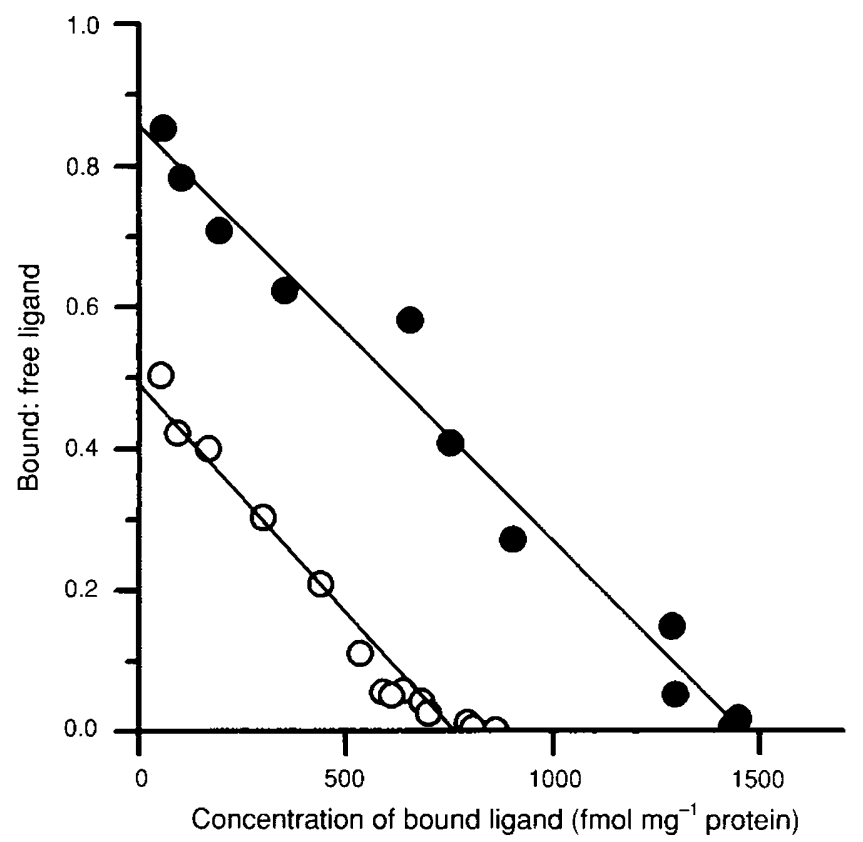

Fig. 4. Equilibrium binding of quinuclidinyl benzylate $\left(\left[{ }^{3} \mathrm{H}\right] \mathrm{QNB}\right)$ to myometrial membranes prepared from control (O) and oestradioltreated $(\bigcirc)$ guinea-pigs. Membranes were incubated at $25^{\circ} \mathrm{C}$ for $60 \mathrm{~min}$ with fixed concentrations $\left(0.01-0.2 \mathrm{nmol} \mathrm{I}^{-1}\right)$ of $\left[{ }^{3} \mathrm{H}\right] \mathrm{QNB}$ with or without increasing concentrations of unlabelled QNB $\left(0.3-10000 \mathrm{nmol} \mathrm{l}^{-1}\right)$; this plot was derived from the fit of two typical curves and each point is the mean of triplicate determinations.

Typical examples of multiple competition curves for $\left[{ }^{3} \mathrm{H}\right] \mathrm{QNB}$ obtained with the myometrial membranes of control and oestradiol-treated animals are shown (Fig. 5).

Figure 6 summarizes the relative potencies of the different ligands for $\left[{ }^{3} \mathrm{H}\right] \mathrm{QNB}$ binding to control and oestradiol-treated guinea-pig myometrium. The abscissa shows the $p \mathrm{Ki}$ value $(-\log$ of the $\mathrm{Ki})$ for the control membranes, while the ordinate shows the $p \mathrm{Ki}$ for the membranes from oestradiol-treated animals. A linear correlation between the $p K i$ values plotted yielded an $r$ value of 0.99 .

\section{Discussion}

This study indicates that biologically active muscarinic receptors are present in the guinea-pig uterus. In addition, it demonstrates for the first time an oestradiol-induced decrease in the number and biological activity of these receptors. Indeed oestrogens stimulate a twofold decrease in $\left[{ }^{3} \mathrm{H}\right] \mathrm{QNB}$ binding, when expressed per mg of protein, and a parallel decrease in uterine responsiveness to cholinergic stimulation, when expressed as a function of maximal $\mathrm{KCl}$-induced contractility. However, when the binding capacity was expressed per DNA, oestradiol had no effect. Similarly, no significant changes induced by oestrogens were found in the contractile force generated by carbachol, as an absolute value. This apparent discrepancy should be interpreted in the light of the real effect of oestradiol on uterine smooth muscle cells: that is, hypertrophy more than hyperplasia. This and previous studies (Michael and Schofield, 1969; Badia et al., 1986) indicate that oestrogens 

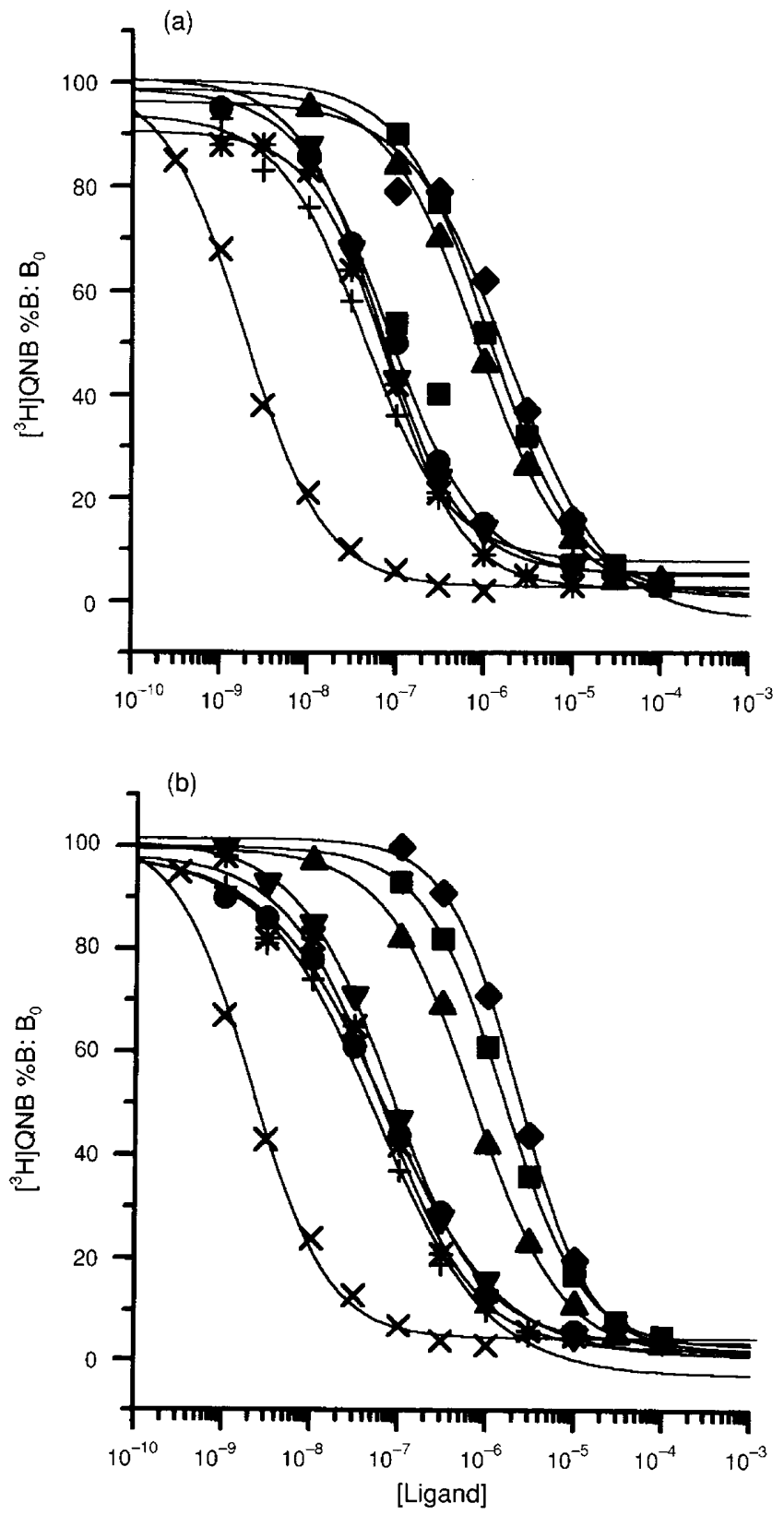

Fig. 5. Antagonist competition curves for quinuclidinyl benzylate $\left.\left({ }^{3} \mathrm{H}\right] \mathrm{QNB}\right)$ binding in myometrial membranes. Membranes from (a) control and (b) oestradiol-treated guinea-pigs were incubated for $60 \mathrm{~min}$ at $25^{\circ} \mathrm{C}$ with $\left.0.2 \mathrm{nmol}\left[{ }^{3} \mathrm{H}\right] \mathrm{QNB}\right]^{-1}$ in the presence or absence of increasing concentrations of several ligands: pirenzepine $(\boldsymbol{\square})$, telenzepine $(\mathbf{O}), \operatorname{AF}-\mathrm{DX} 116(\boldsymbol{\Delta})$, methoctramine $(\boldsymbol{\nabla}), p$-F$\operatorname{HHSiD}(\bullet)$, 4-DAMP $(+), \mathrm{S}-(-)$-hyoscyamine $(x)$, and $\mathrm{R}-(+)$ hyoscyamine $(*)$. The data are plotted as percentages of maximal binding and were analysed by interactive nonlinear regression; values are the means of three different experiments, each carried out in triplicate.

increase the contractile network in the uterus and induce marked changes in protein content and uterine weight more than a clear-cut increase in the number of cells. Hence, the substantial stability of the number of muscarinic receptors per cell corresponds to a functional decrease in the real density and biological activity.

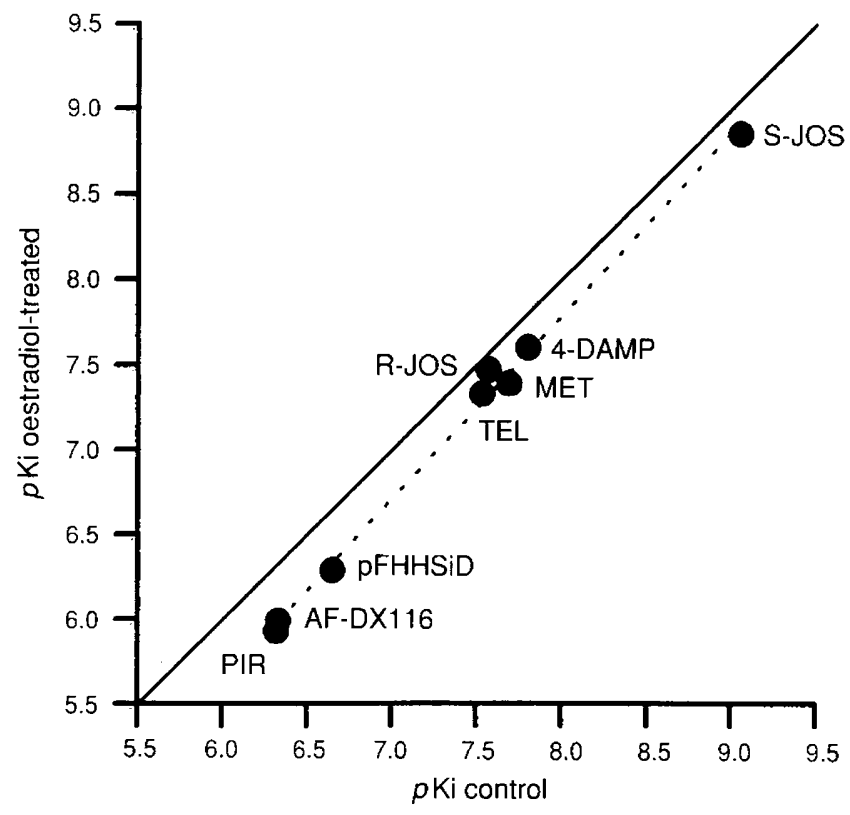

Fig. 6. Graphical representation of the selectivity of several ligands for the binding of quinuclidinyl benzylate $\left(\left[{ }^{3} \mathrm{H}\right] \mathrm{QNB}\right)$ to membranes prepared from myometrium of control and oestradiol-treated guineapigs. Aliquots of membranes were incubated in the presence of $0.2 \mathrm{nmol} \mathbf{1}^{-1}$ labelled ligand and increasing concentrations of unlabelled drugs $\left(10^{-10}-10^{-5} \mathrm{~mol} \mathrm{l}^{-1}\right)$. The solid line represents the line of identity ( $p \mathrm{Ki}$ control $=p \mathrm{Ki}$ oestradiol-treated), whereas the dotted line represents the normal regression line $(r=0.99)$. PIR, pirenzepine; TEL, telenzepine; MET, methoctramine; S-JOS, S- $(-)$-hyoscyamine; R-JOS, R-( + )-hyoscyamine.

Because the rank order of potency of several cholinergic ligands is identical in control and oestradiol-treated animals, we infer that oestradiol induces a real decrease in receptor density more than a switch in receptor subtype expression. On the basis of ligand selectivity of the muscarinic receptor found in the guinea-pig uterus, it is difficult to identify definitively the subtype of receptor present. Nevertheless, our results are compatible with the predominant expression of the $\mathrm{M}_{2}$ receptor subtype in the guinea-pig uterus (Eglen et al., 1989, 1991; Doods et al., 1993).

The muscarinic receptors identified in the guinea-pig uterus mediate a rather potent stimulation of myometrial contractility that is three times greater than $\mathrm{KCl}$. Since the endometrium contains biologically active muscarinic receptors (Weiss and Gurpide, 1988), and is able to produce uterotonic substances such as oxytocin (Lefebvre et al., 1992) and endothelin-1 (Orlando et al., 1990), we investigated the relative contribution of the endometrial layer to the contractile activity of carbachol. Careful removal of the endometrial layer (as indicated by serial histological evaluation) did not affect maximal myometrial responsiveness to cholinergic stimulation in either treated or untreated animals.

These findings indicate that the uterotonic effect of carbachol is independent of the release of endometrial factors and is mediated by receptors present on smooth muscle fibres. The results are in apparent contrast to a previous study in the rabbit uterus, which showed lower cholinergic sensitivity in 
scraped myometrial strips (Riemer et al., 1986). Conflicting results may derive from interspecies variations or from different procedures of endometrial removal.

These results on the negative effect of oestrogens on myometrial muscarinic receptor density are relatively surprising. In fact, oestrogens generally sensitize more than desensitize the uterus to the action of uterotonic substances. However, the results are in agreement with a previous report on a lower responsiveness of uterine strips to acetylcholine in oestrogenprimed ovariectomized guinea-pigs (Garris et al., 1984). In addition, they are in keeping with results obtained in the pregnant rabbit uterus at term: a physiological model of an oestrogen-dominant uterus (Riemer et al., 1986). Indeed, the maximal uterine response to carbachol showed a threefold decrease between day 30 and day 31 of pregnancy (Riemer et al., 1986). These results, together with the demonstration of cholinergic denervation in the pregnant uterus at term (Wikland et al., 1984; Morizaki et al., 1989), indicate that hormonal factors, more than cholinergic transmission, are important in controlling the contractile activity of the oestrogen-dominant uterus. This oestrogen-induced relative insensitivity to cholinergic influence may have physiological significance at the end of pregnancy, when the maternal myometrium should be selectively sensitive to appropriate hormonal messages for the initiation of the labour process.

The authors thank R. Zonefrati (Institute of Internal Medicine and Immunoallergology, University of Florence, Florence) for his excellent assistance in the DNA measurements. This work was supported by grants from Ministero dell' Università e della Ricerca Scientifica e Tecnologica (MURST) and Consiglio Nazionale delle Ricerche (CNR).

\section{References}

Badia E, Nicolas JC, Haiech J and De Paulet AC (1986) Effect of steroid hormones on the regulation of uterine contractility Pflügers Archiv 407 670-676

Barlow RB, Berry KJ, Glenton PAM, Nikolaou NM and Soh KS (1976) A comparison of affinity constants for muscarinic-sensitive acetylcholine receptors in guinea-pig atrial pacemaker cells at $29^{\circ} \mathrm{C}$ and ileum at $29^{\circ} \mathrm{C}$ and $37^{\circ} \mathrm{C}$ British Journal of Pharmacology $58613-620$

Bradford M (1976) A rapid and sensitive method for the quantification of microgram quantities of protein in utilizing the principle of protein-dye binding Analytical Biochemistry 72 248-254

Crankshaw DJ (1984) Muscarinic cholinoceptors in the rabbit's myometrium: a study of the relationship between binding and response European Journal of Pharmacology 110 I-10

De Lean A, Munson PJ and Rodbard D (1978) Simultaneous analysis of families of sigmoidal curves: application to bioassay, radioligand assay, and physiological dose-response curves American Journal of Physiology 2.35 E97-E102

Doods HN, Willim KD, Boddeke HWGM and Entzeroth M (1993) Characterization of muscarinic receptors in guinea-pig uterus European Journal of Pharmacology 250 223-230

Eglen RM, Michel AD and Whiting RL (1989) Characterization of the muscarinic receptor subtypes mediating contractions of the guinea-pig uterus British Journal of Pharmacology 96 497-499

Eglen RM, Michel AD, Levine WB and Whiting RL (1991) Analysis of muscarinic receptors in guinea-pig oestrogen-dominated uterus, in vitro British Journal of Pharmacology $10443 \mathrm{P}$

Garris DR, Ingenito AJ, McConnaughey MM and Dar MS (1984) Regulation of estrogen-induced uterine hyperemia and contractility in the guinea pig: cholinergic modulation of an alpha-adrenergic response Biology of Reproduction $30863-868$
Gualtieri F, Romanelli MN, Scapecchi S, Teodori E, Bartolini A, Fantetti L, Ghelardini C and Giotti A (1991) Muscarinic presynaptic autoreceptors and muscarinic postsynaptic receptors have opposite stereochemical requirements Medical Chemical Research 1 50-58

Hammer R and Giachetti A (1982) Muscarinic receptors subtypes: $M_{1}$ and $M_{2}$, biochemical and functional characterization Life Sciences 31 2991-2998

Hammer R, Berrie CP, Birdsall NJM, Burgen ASV and Hulme EC (1980) Pirenzepine distinguishes between different subclasses of muscarinic receptors Nature $\mathbf{2 8 3} 90-92$

Ichida S, Tokunaga H, Oda Y, Fujita N, Hirata A and Hata T (1983) Increase of serotonin receptors in rat uterus induced by estradiol Journal of Biological Chemistry 258 13 $438-13443$

Ichida S, Oda Y, Tokunaga H, Hayashi T, Murakami T and Kita T (1984) Mechanisms of specific change by estradiol in sensitivity of rat uterus to serotonin Journal of Pharmacology and Experimental Therapeutics 229 244-249

Labarca C and Paigen K (1980) A simple, rapid, and sensitive DNA assay procedure Analytical Biochemistry 102 344-352

Lambrecht G, Feifel R, Wagner-Roder M, Strohmann C, Zilch H, Tacke R, Waelbroeck M, Christophe J, Boddeke H and Mutschler E (1989) Affinity profiles of hexahydro-sila-difenidol analogues at muscarinic receptor subtypes European Journal of Pharmacology 168 71-80

Lefebvre DL, Giaid A, Bennett H, Lariviere R and Zingg HH (1992) Oxytocin gene expression in rat uterus Science 256 1553-1555

Leiber D, Harbon S, Guillet JG, Andrè C and Strosberg AD (1984) Monoclonal antibodies to purified muscarinic receptor display agonist-like activity Proceedings of the National Academy of Sciences USA $814331-4334$

Maggi M, Genazzani AD, Giannini S, Torrisi C, Baldi E, Di Tomasso M, Munson PJ, Rodbard D and Serio M (1988) Vasopressin and oxytocin receptors in vagina, myometrium, and oviduct of rabbits Endocrinology 122 2970-2980

Maggi M, Vannelli GB, Peri A, Brandi ML, Fantoni G, Giannini S, Torrisi C, Guardabasso V, Barni T, Toscano V, Massi G and Serio M (1991) Immunolocalization, binding and biological activity of endothelin in rabbit uterus: effect of ovarian steroids American Journal of Physiology 260 E292-E305

Maggi M, Baldi E and Susini T (1994a) Hormonal and local regulation of uterine activity during parturition: part $\mathrm{I}$ - the oxytocin system Journal of Endocrinological Investigation 17 739-756

Maggi M, Baldi E and Susini T (1994b) Hormonal and local regulation of uterine activity during parturition: part $\mathrm{Il}$ - the prostaglandin and adrenergic system Journal of Endocrinological Investigation 17 739-756

Marc S, Lieber D and Harbon S (1986) Carbachol and oxytocin stimulate the generation of inositol phosphates in the guinea pig myometrium FEBS Letters $2019-14$

Melchiorre C, Angeli P, Lambrecht G, Mutschler E, Picchio MT and Wess J (1987) Antimuscarinic action of methoctramine, a new cardioselective $\mathrm{M}_{2}$ muscarinic antagonist alone and in combination with atropine and gallamine European Joumal of Pharmacology 144 117-124

Michael CA and Schofield BM (1969) The influence of the ovarian hormones on the actomyosin content and the development of tension in uterine muscle Journal of Endocrinology 44501-511

Micheletti R, Montagna E and Giachetti A (1987) AF-DX 116, a cardioselective muscarinic antagonist Journal of Pharmacology and Experimental Therapeutics $241628-634$

Morizaki N, Morizaki J, Hayashi RH and Garfield RE (1989) A functional and structural study of the innervation of the human uterus American Journal of Obstetrics and Gynecology $160218-228$

Munson PJ and Rodbard D (1980) LIGAND: a versatile computerized approach for characterization of ligand-binding systems Analytical Biochemistry 107 $220-239$

Orlando C, Brandi ML, Peri A, Giannini S, Fantoni G, Calabresi E, Serio M and Maggi M (1990) Neurohypophyseal hormone regulation of endothelin secretion from rabbit endometrial cells in primary culture Endocrinology 126 $1780-1783$

Parkington HC and Lipton A (1976) Sustained effects of synthetic ovarian steroids on rat myometrial contractility Journal of Endocrinology 70 223-227

Riemer RK, Goldfien AC and Roberts JM (1986) Rabbit uterine oxytocin receptors and in vitro contractile response: abrupt changes at term and the role of eicosanoids Endocrinology 119 699-709

Riemer RK, Goldfien A and Roberts JM (1987a) Rabbit myometrial adrenergic sensitivity is increased by oestrogen but is independent of changes in alpha adrenoceptor concentration Journal of Pharmacology and Experimental Therapeutics $24044-50$ 
Riemer RK, Goldfien A and Roberts JM (1987b) Oestrogen increases adrenergic but not cholinergic mediated production of inositol phosphates in rabbit uterus Molecular Pharmacology 32 663-668

Roberts JM, Insel PA, Goldfien RD and Goldfien A (1977) a-Adrenoceptors but not $\beta$-adrenoceptors increase in rabbit uterus with oestrogen Nature 270 $624-625$

Varol FG, Hadjiconstantinou M, Zuspan FP and Neff NH (1989) Gestational alterations in phospholipase $C$ coupled muscarinic response Life Sciences 45 $1739-1743$
Weiss JD and Gurpide E (1988) Regulation of phosphoinositide hydrolysis in transformed human endometrial cells Endocrinology 123 981-990

Wikland M, Lindblom BO, Dahestrom A and Haglid KG (1984) Structural and functional evidence for the denervation of human myometrium during pregnancy Obstetrics and Gynecology 64 503-509 